\title{
EU policy on healthy ageing
}

\author{
Włodzimierz Cezary Włodarczyk ${ }^{1}$ (1) https://orid.org/0000-0001-9616-391x \\ Marzena Tambor ${ }^{2}$ (1D https://orcid.org/0000-0001-7970-6919
}

${ }^{1}$ Health Policy and Management Department, Institute of Public Health, Faculty of Health Sciences, Jagiellonian University Collegium Medicum

2 Department of Health Economics and Social Security, Institute of Public Health, Faculty of Health Sciences, Jagiellonian University Collegium Medicum

Address for correspondence: Marzena Tambor, Institute of Public Health, Jagiellonian University Collegium Medicum, Grzegorzecka 20,31-531 Cracow, Poland, +48 1243328 09, Fax: +48 12421 74 47, marzena.tambor@uj.edu.pl

\section{Abstract}

Population ageing has been affecting all countries across the European Union (EU). To address the challenges resulting from this process, a healthy ageing strategy has been proposed. Healthy ageing aims at keeping older people in good health and independent as long as possible, and thus, improves their wellbeing. The aim of this paper is to present the EU healthy ageing policy, based on a review of EU documents related to this concept. A method of narrative literature review using a snowball approach has been applied.

The results of the review show that healthy ageing is a broad concept which covers various issues, such as promoting health enhancing behaviour, disease prevention, changing the social perception of older people and providing conditions for the independent living of older people. Healthy ageing has often been dominated by active ageing strategies which are focused on increasing older people's labour market participation and social involvement. The EU actions in the area of healthy ageing include: increasing awareness and encouraging relevant stakeholders to undertake actions to address the needs of older people (e.g. the 2012 European Year for Active Ageing and Solidarity between Generations), providing funds (e.g. Health Programmes) and providing platforms for cooperation and exchange of good practices (e.g. the European Innovation Partnership on Active and Healthy Ageing).

\section{Key words: active ageing, healthy ageing, European Union, policy \\ Stowa kluczowe: aktywne starzenie sie, zurowe starzenie sie, Unia Europejska, polityka}

\section{Funding}

This paper arises from the project Pro-Health65 + which has received funding from the European Union, in the framework of the Health Programme (2008-2013). The content of this paper represents the views of the author and it is his sole responsibility; it can in no way be taken to reflect the views of the European Commission and/or the Executive Agency for Health and Consumers or any other body of the European Union. The European Commission and/or the Executive Agency do(es) not accept responsibility for any use that may be made of the information it contains. The work of authors from JUMC is also financed from funds for science in the years 2015-2017, allocated for implementation of international co-financed projects.

Conflict of interest: none.

Ministerstwo Nauki

i Szkolnictwa Wyższego
Przygotowanie do wydania elektronicznego finansowane w ramach umowy 637/P-DUN/2019 ze środków Ministerstwa Nauki i Szkolnictwa Wyższego przeznaczonych na działalność upowszechniającą naukę. 


\section{Introduction}

Population ageing, as a result of low fertility rates and increasing life expectancy, has been affecting all countries across the European Union (EU). The population prognosis indicates that the share of older persons in the total population will increase significantly in the coming decades, and by 2030 , nearly one fourth $(24 \%)$ of the EU population will be $65+[1]$. This situation poses significant economic and social challenges, such as increased costs of health care and social security systems, a shrinking economically active population and thus, curbed economic growth [2]. Deteriorating health and increasing disability, which lead to limitations in everyday functioning, also significantly affect the wellbeing of older people [3].

Within this context, a healthy ageing strategy has emerged, which aims at keeping older people in good health and independent as long as possible, and by this means, mitigates the negative effects of ageing on the population and, more importantly, on older people themselves. The concept of healthy ageing was introduced by the WHO in the 1990s in the updated version of Health for All 2000 targets for Europe (1991) [4] which stressed the need for sustained and continuing improvement in the health of all people aged 65 years and over. The WHO has acknowledged that 'increased longevity without quality of life is an empty prize' and that 'health expectancy is more important than life expectancy'[5]. Prevention and health promotion have been indicated as a core component of healthy ageing, assuming that it is never too late to promote health [5].

Healthy ageing is related to other ageing concepts; most often active ageing. These two terms are often used interchangeably, though there are some underlying differences indicated in the literature. Namely, the concept of active ageing is seen to place a greater emphasis on maintaining labour market participation and overall functional capacity, but is however, often dominated by 'a narrow productivist perspective' [6-7]. Remaining active requires good health, and in this sense, active ageing can be seen as a broader concept which comprises healthy ageing strategies. Nevertheless, while a concept of active ageing strongly indicates the benefits for society, i.e. reducing the overall cost of ageing to society, healthy ageing emphasizes the benefits for older people themselves and for their wellbeing [6].

In its early years, the EU, and its predecessor, European Communities, focused on economic issues, and it took some time before the significance of social facets of development, including health and ageing [7], were appreciated. The reconsideration of the ultimate purposes of European integration ('reflections' [8]) has been repeated a number of times and problems of health have played an important role in this evolution [9]. Once presented, the concept of healthy ageing has enjoyed a growing popularity in recent years and, along with active ageing, has become a strategy promoted by the EU [2, 10-12]. Healthy ageing is indicated as the keystone for economic prosperity in Europe, thus contributing to the achieve- ment of the Europe 2020 objectives of smart, sustainable and inclusive growth [12-14]. Although EU authority to shape members state health policy are limited [15], the EU plays an important role in increasing awareness among policy makers in member states, calling on them to undertake actions to respond to presented challenges and indicating directions for policies.

The aim of this paper is to present EU healthy ageing policy, based on a review of EU documents related to this concept. We attempt to identify the directions that the EU is giving for country-level healthy ageing policies. Such analysis might spur discussion on healthy ageing policies in the member states and facilitate national, regional and local health policy makers in their actions to respond to population ageing. We also discuss the strengths of EU healthy ageing initiatives as well as their shortcomings, which we believe can contribute to improvement of the EU healthy ageing policy.

The methodological approach to our analysis and the main sources of the information are presented in the Materials and Methods section. The Results section includes the key points of the EU healthy ageing policy. Discussion and Conclusions complete the paper.

\section{Materials and methods}

To present the EU healthy ageing strategy, a method of narrative literature review has been applied, focusing on EU documents. It is a non-systematic method with a less rigorous approach to identify and synthesize evidence than a systematic literature review. The review was targeted at EU documents. To search for relevant documents, we employed a snowballing approach using key documents as a starting point [16]. Then, references to other EU documents were reviewed to identify a set of most relevant documents related to healthy ageing. The documents were selected as relevant if they dealt with the issues of healthy ageing, i.e. maintaining the health of older people through health promotion and disease prevention. The documents were searched largely through the European database EUR-Lex which provides access to EU law and other public EU documents. To limit selection bias (i.e. missing relevant documents) due to the non-systematic approach, we validated our search results by comparing them to the results of systematic literature reviews conducted by others $[12,17]$. The list of selected documents is included in Table I. A qualitative synthesis of evidence was performed in order to analyse and summarize the gathered evidence on the EU healthy ageing policy. The results are presented in a narrative manner in the next section.

\section{Results}

\section{Ageing of population as an EU policy issue}

The ageing of the European population had already become an important policy issue for the EU in the 1990s. These demographic changes required actions to increase the awareness of societies and policy makers in European 


\begin{tabular}{|c|c|c|}
\hline Content of document & Type of document & Source \\
\hline Community Actions for the Elderly & Council Decision & $\begin{array}{l}\text { Council of the European Communities, 1990, } \\
\text { http://eur-lex.europa.eu/legal-content/EN/TXT/HTML/?uri= } \\
\text { CELEX:31991D0049\&rid=1 }\end{array}$ \\
\hline $\begin{array}{l}\text { The European Year of the Elderly and of Solida- } \\
\text { rity between Generations (1993) }\end{array}$ & Council Decision & $\begin{array}{l}\text { Council of the European Communities, 1992, } \\
\text { http://eur-lex.europa.eu/legal-content/EN/TXT/HTML/?uri= } \\
\text { CELEX:31992D0440\&rid=1 }\end{array}$ \\
\hline $\begin{array}{l}\text { Towards a Europe for All Ages - Promoting } \\
\text { Prosperity and Intergenerational Solidarity }\end{array}$ & $\begin{array}{l}\text { Communication from the } \\
\text { Commission }\end{array}$ & $\begin{array}{l}\text { Commission of the European Communities, 1999, } \\
\text { http://ec.europa.eu/employment_social/social_situation/docs/ } \\
\text { com221_en.pdf }\end{array}$ \\
\hline $\begin{array}{l}\text { Towards a Europe for All Ages - Promoting } \\
\text { Prosperity and Intergenerational Solidarity }\end{array}$ & $\begin{array}{l}\text { European Parliament Reso- } \\
\text { lution on the Commission } \\
\text { Communication }\end{array}$ & $\begin{array}{l}\text { European Parliament, } 2000 \text {, } \\
\text { http://eur-lex.europa.eu/legal-content/EN/TXT/PDF/?uri=CE } \\
\text { LEX:52000IP0319\&rid=1 }\end{array}$ \\
\hline $\begin{array}{l}\text { Europe's Response to World Ageing. Promoting } \\
\text { Economic and Social Progress in an Ageing } \\
\text { World. A Contribution of the European Com- } \\
\text { mission to the 2nd World Assembly on Ageing }\end{array}$ & $\begin{array}{l}\text { Communication from the } \\
\text { Commission to the Council } \\
\text { and the European Parliament }\end{array}$ & $\begin{array}{l}\text { Commission of the European Communities, 2002, } \\
\text { http://ec.europa.eu/employment_social/social_situation/docs/ } \\
\text { com2002_0143_en.pdf }\end{array}$ \\
\hline $\begin{array}{l}\text { Healthy Ageing: Keystone for a Sustainable } \\
\text { Europe: EU Health Policy in the Context of } \\
\text { Demographic Change }\end{array}$ & Discussion paper & $\begin{array}{l}\text { European Commission Directorate-General for Health and } \\
\text { Food Safety, 2007, http://ec.europa.eu/health/ph_information/ } \\
\text { indicators/docs/healthy_ageing_en.pdf }\end{array}$ \\
\hline Healthy and Dignified Ageing & Council conclusions & $\begin{array}{l}\text { Council of the European Union, 2009, } \\
\text { http://www.salute.gov.it/imgs/C_17_pagineAree_2406_lista- } \\
\text { File_itemName_2_file.pdf }\end{array}$ \\
\hline Active Ageing & Council conclusions & $\begin{array}{l}\text { Council of the European Union, } 2010 \text {, } \\
\text { http://www.consilium.europa.eu/uedocs/cms_data/docs/press- } \\
\text { data/en//sa/114968.pdf }\end{array}$ \\
\hline $\begin{array}{l}\text { Dealing with the Impact of an Ageing Popula- } \\
\text { tion in the EU (2009 Ageing Report) }\end{array}$ & $\begin{array}{l}\text { Communication from the } \\
\text { Commission to the European } \\
\text { Parliament, the Council, the } \\
\text { European Economic and } \\
\text { Social Committee and the } \\
\text { Committee of the Regions }\end{array}$ & $\begin{array}{l}\text { Commission of the European Communities, 2009, } \\
\text { http://www.igfse.pt/upload/docs/gabdoc/2009/Novidades/05- } \\
\text {-Mai/Communication_Dealing_with_the_impact_of_an_age- } \\
\text { ing_population_en.pdf }\end{array}$ \\
\hline $\begin{array}{l}\text { Demographic Challenge and Solidarity between } \\
\text { Generations }\end{array}$ & Report & $\begin{array}{l}\text { European Parliament: Committee on Employment and Social } \\
\text { Affairs, 2010, } \\
\text { http://www.europarl.europa.eu/sides/getDoc. } \\
\text { do?type=REPORT\&reference=A7-2010-0268\&language=EN }\end{array}$ \\
\hline $\begin{array}{l}\text { The European Year for Active Ageing and } \\
\text { Solidarity between Generations (2012) }\end{array}$ & $\begin{array}{l}\text { Decision of the European } \\
\text { Parliament and Council of } \\
\text { the European Union }\end{array}$ & $\begin{array}{l}\text { European Parliament and Council of the European Union, } \\
\text { 2011, } \\
\text { http://eur-lex.europa.eu/legal-content/EN/TXT/PDF/?uri=CE } \\
\text { LEX:32011D0940\&from=EN }\end{array}$ \\
\hline $\begin{array}{l}\text { The European Year for Active Ageing and } \\
\text { Solidarity between Generations (2012): The } \\
\text { Way Forward }\end{array}$ & Council declaration & $\begin{array}{l}\text { Council of the European Union, } 2012 \text {, } \\
\text { http://register.consilium.europa.eu/doc/srv?1=EN\&f=ST\%20 } \\
17468 \% 202012 \% 20 \text { INIT }\end{array}$ \\
\hline Healthy Ageing across the Lifecycle & Council conclusions & $\begin{array}{l}\text { Council of the European Union, 2012, } \\
\text { http://eur-lex.europa.eu/legal-content/EN/ALL/?uri=CELEX } \\
\text { \%3A52012XG1221(01) }\end{array}$ \\
\hline $\begin{array}{l}\text { Taking forward the Strategic Implementation } \\
\text { Plan of the European Innovation Partnership on } \\
\text { Active and Healthy Ageing }\end{array}$ & $\begin{array}{l}\text { Communication from the } \\
\text { Commission to the European } \\
\text { Parliament and the Council }\end{array}$ & $\begin{array}{l}\text { European Commission, 2012, } \\
\text { http://ec.europa.eu/health/ageing/docs/com_2012_83_en.pdf }\end{array}$ \\
\hline $\begin{array}{l}\text { Adopting a Programme of Community Action in } \\
\text { the Field of Public Health (2003-2008) - Com- } \\
\text { mission Statements }\end{array}$ & Decision & $\begin{array}{l}\text { European Parliament and Council of the European Union, } \\
\text { 2002, } \\
\text { http://eur-lex.europa.eu/legal-content/EN/ } \\
\text { TXT/?uri=CELEX:32002D1786 }\end{array}$ \\
\hline $\begin{array}{l}\text { Establishing a Second Programme of Communi- } \\
\text { ty Action in the Field of Health (2008-2013) }\end{array}$ & Decision & $\begin{array}{l}\text { European Parliament and Council of the European Union, } \\
\text { 2007, } \\
\text { http://eur-lex.europa.eu/legal-content/EN/ } \\
\text { TXT/?uri=celex:32007D1350 }\end{array}$ \\
\hline $\begin{array}{l}\text { Establishment of a third Programme for } \\
\text { the Union's Action in the Field of Health } \\
(2014-2020)\end{array}$ & Regulation & $\begin{array}{l}\text { European Parliament and of the Council, 2014, } \\
\text { http://eur-lex.europa.eu/legal-content/en/ } \\
\text { TXT/?uri=CELEX\%3A32014R0282 }\end{array}$ \\
\hline $\begin{array}{l}\text { Participation of the Union in the Active and } \\
\text { Assisted Living Research and Development } \\
\text { Programme Jointly Undertaken by Several } \\
\text { Member States }\end{array}$ & Decision & $\begin{array}{l}\text { European Parliament and of Council of the European Union, } \\
\text { 2014, } \\
\text { http://eur-lex.europa.eu/legal-content/EN/TXT/?qid=1501523 } \\
\text { 867409\&uri=CELEX:32014D0554 }\end{array}$ \\
\hline
\end{tabular}

Table I. The list of reviewed documents.

Source: Own study. 
countries about the ageing process and its consequences. In 1990, the Council of the European Communities issued the 'Decision on community actions for the elderly' [18] which covered a period of three years (1991-1993) with the last year being designated the European Year of Older People and Solidarity between Generations [19]. These initiatives opened a European discourse on ageing and measures to face its economic and social challenges.

The activities of the EU in that time were mainly focused on raising the employment rate among older people and consequently achieving the sustainability of pension systems. This economistic focus of EU policy was accelerated by the goals declared in the European Employment Strategy (1997) and The Lisbon Strategy (2000), aimed at making 'Europe the most competitive and dynamic knowledge-based economy in the world'[20]. Nevertheless, the EU acknowledged that older people can contribute to societies in many ways, and it also aimed at highlighting the positive contribution of the elderly to societies and strengthening the solidarity between generations and promoting the integration of older people. Also, lifelong learning was seen as being important not only in relation to paid employment or the labour market but also in non-professional life. Importantly, the EU also recognized that older people are not a homogeneous group and that well-tailored programmes are necessary to address their needs, including the needs of the oldest among the old (75+) [21].

Health promotion was not a common topic in EU documents and, when mentioned, it was grouped with active ageing measures. In the European Commission's communication titled 'Towards a Europe for All Ages - Promoting Prosperity and Intergenerational Solidarity’ (1999) [22], health promotion and disease prevention over curative approaches, were indicated as one of the proposed strategies to respond to the health needs of older people. Capacity enhancing and health sustaining activities were also listed by the European Commission in its contribution to $2^{\text {nd }}$ UN World Assembly on Ageing - 'Europe's response to World Ageing. Promoting economic and social progress in an ageing world' (2002), as some of the core active ageing practices (together with life-long learning, working longer, retiring later and, more gradually, being active after retirement). The active ageing concept was presented as 'win-win strategies for people of all ages', as it benefited both; the society by decreasing the burden of ageing, and older people by improving their quality of life [23]. The European Commission also pointed out the link between being healthy and being active, although the ultimate goal was labour participation and social benefits; i.e. keeping older people healthier increases their labour participation and decreases the need for health care and, consequently, pressure on public finances [24].

\section{Towards a greater focus on healthy ageing}

An increased attention to the health and well-being of older people can be seen in a discussion paper by the European Commission Directorate-General for Health and
Food Safety - 'Healthy ageing: keystone for a sustainable Europe' (2007) [11]. The document indicated that the EU's health policy was unequivocally to increase Healthy Life Years (an indicator used to estimate how many years a person can expect to live without illness or disability, also called disability-free life expectancy) through reasonably tailored ageing policy across all sectors. One of the ageing policy priorities referred to health promotion and disease prevention, though it was noted that to be effective they could not only be focused on older people and that a lifespan (life cycle) approach is necessary, as poor health in old age is often the result of an accumulation of risk factors throughout the life course. An important area of EU activities indicated in the document were related to the major risk factors of the biggest killers (cardiovascular disease and diabetes), such as high blood pressure, smoking, being overweight, poor diet and alcohol abuse. Also, the document stressed the need to cope with mental health problems common among older people by eliminating the isolation of older people or encouraging physical and social participation in older age.

Healthy ageing was also highlighted as a priority during the Swedish Presidency of the Council of the European Union. In its conclusions on "Healthy and Dignified Ageing" (2009) [25], the Council invited member states to make the issue of healthy and dignified ageing one of their priorities, and to adopt an approach that shifts the focus towards preventive measures as a strategy to improve quality of life and reduce the burden of chronic diseases, frailty and disability. The European Commission was invited to develop an action plan for promoting dignity, health and quality of life for older people and supporting countries in their activities. It was proposed that the year 2012 be dedicated to Active Ageing and Intergenerational Solidarity.

The ageing theme was continued during the Spanish Presidency of the European Union in 2010, though it was more focused on active ageing, highlighting the benefits and opportunities that the economic and social participation of older people would provide to society (the silver economy) [26]. In 2012, the Council of the European Union, in its conclusions 'Healthy Ageing across the Lifecycle' [27] renewed its invitation to make the issue of healthy ageing across the lifecycle one of European countries' priorities. Health promotion, disease prevention throughout the lifecycle and better management of long-term health conditions were proposed as strategies to improve the quality of life of older people. European countries and the European Commission were encouraged to implement policies to combat risk factors, such as tobacco use, alcohol related harm, illicit drugs, unhealthy diet and lack of physical activity, as well as environmental factors leading to increased incidence of non-communicable chronic diseases, such as cancer, respiratory diseases, cardiovascular and neurovascular diseases, diabetes, mental illnesses and musculoskeletal disorders. Moreover, the need to identify, promote and share good practices in addressing chronic diseases and their risk factors, was indicated. 


\section{European Year for Active Ageing and Solidarity between Generations}

The European Commission, together with the European Parliament and the European Council, dedicated 2012 as the European Year for Active Ageing and Solidarity between Generations (EY 2012) [28]. The overall objective of the European Year was to facilitate the creation of an active ageing culture in Europe based on a society for all ages. All relevant stakeholders were invited to promote active ageing and to enhance their efforts to mobilize the potential of older people. Healthy ageing in dignity was indicated as one of the elements of active ageing strategy, along with maintaining labour market participation, combating poverty and social exclusion, as well as fostering volunteering and active participation in family life and society.

The EY 2012 and the measures implemented to meet its objectives, i.e. conferences, debates, educational campaigns and the exchange of experience and good practices were generally seen as great achievements [29]. They increased awareness and inspired national governments to develop their senior policies as well as civil society organizations to undertake actions targeted at older people. Yet, it was assessed that further actions needed to be implemented to fulfil the general objective, i.e. creating an active ageing culture in Europe. The EY 2012 also inspired researchers to develop the Active Ageing Index, which is a tool to measure the untapped potential of older people, for active and healthy ageing across countries. It measures the level to which older people (1) participate in paid employment; (2) participate in social activities; (3) live independent healthy and secure lives, and 4) the capacity and degree of environments to enable active ageing [30].

\section{The European Innovation Partnership on Active and Healthy Ageing}

The European Innovation Partnership on Active and Healthy Ageing is the EU platform for sharing experiences and collaboration between various stakeholders in the field of active and healthy ageing. It was officially launched by the EU in 2011, as one of the flagship initiatives of the newly established European growth strategy, Europe 2020 (the successor to the Lisbon strategy), which aimed at smart, sustainable and inclusive growth. In the founding document it was openly declared that supporting active and healthy ageing was important both to improve the quality of life of elderly citizens and to help them to contribute to society as they grow older. Its overarching objective is to increase the number of Healthy Life Years by two before 2020, by improving health and quality of life (with a focus on older people); ensuring that health and social care systems are sustainable and efficient in the long term and enhancing the competitiveness of EU industry through business and expansion into new markets [31]. The Partnership's Strategic Implementation Plan, adopted by a Steering Committee in 2011, focused on actions de- veloped around three pillars: (1) prevention, screening and early diagnosis of potential problems; (2) care and cure, and (3) active ageing and independent living [32].

\section{EU funding programmes for healthy ageing}

The EU supports member states in their actions to promote health among older people through various funding programmes. The most significant funding programmes for healthy ageing are the three subsequent health programmes. In the first health programme for 2003-2008 [33], healthy ageing was not clearly included and health of elderly people was seen as an element of good health of the population in general - which was the overall aim of the health programme. Nevertheless, the need to prepare age-specific health promotion and disease prevention strategies on life-style related health determinants, such as nutrition, physical activity, tobacco, alcohol, drugs and other substances, and on mental health, was indicated. Under this programme, in 2003, the Swedish National Institute of Public Health, together with other partners, initiated the 'Healthy Ageing' project. The project made recommendations to EU institutions and member states and spurred a discussion on healthy ageing. Under the project, a commonly accepted definition of healthy ageing was also developed, which reads as follows: 'healthy ageing is the process of optimizing opportunities for physical, social and mental health to enable older people to take an active part in society without discrimination and to enjoy an independent and good quality of life' [2]. The topic of healthy ageing gained more attention in the Second Health Programme (2008-2013) [34]. Under the second theme of promoting health, the programme funded actions to increase healthy life years and promote healthy ageing. In the third Health Programme for 2014-2020, one of the priorities is to support actions which address health issues in an ageing society, including relevant actions suggested by the European Innovation Partnership on Active and Healthy Ageing [35].

Worth mentioning are also joint programmes such as the Active and Assistive Living Programme (AAL), the More Years, Better Lives Joint Programme (MYBL) or the EU Joint Programme - Neurodegenerative Disease Research (JPND). The first among them, the Active and Assistive Living Programme (AAL) (2014-2020), which replaced the Ambient Assisted Living Joint Programme (2008-2013), is a joint initiative of the EU - under the Horizon 2020 umbrella - and member states. The programme funds projects in public-private partnership in the field of information and communication technology (ICT) for active and healthy ageing to strengthen industrial opportunities in Europe through the use of ICT on the one hand, and improving the quality of life of older people on the other hand [36].

\section{Discussion}

The results of our review show that healthy ageing is a broad concept which covers various issues, such as health enhancing behaviour (e.g. physical activity), dis- 
ease prevention (particularly, falls prevention or mental disorders), changing the perception of older people in society and providing conditions for the independent living of older people. The first EU activities (begun in the 1990s') were more strongly related to the concept of active ageing, i.e. increasing older people's participation in the labour market and social participation, so that older persons would remain a resource to their families, communities and economy. Later, the concept of healthy ageing, aimed at keeping people healthy in order to improve their well-being, gained more attention. Nevertheless, the two concepts, i.e. healthy ageing and active ageing, often appear together and they can be seen as two sides of the same coin. It is recognized that good health is a precondition for active life in older age. However, keeping older people active might also contribute to maintaining their health in its multi-dimensional meaning, i.e. physical, mental and social. Although a blurred line between healthy ageing and active ageing is understandable, it might incline policy makers to focus their efforts on keeping older people active, especially in the labour market, neglecting health promotion and disease prevention. This approach may be productive if applied to younger segments, but is misleading with regard to older segments of the elderly population.

The 'primarily economistic or productivity focus' of EU policy has already been noted in the literature [10]. This can be explained by the increasing financial pressure for solutions which can bring immediate benefits for social systems and the economy. The benefits from health promotion are, however, less tangible. Although healthy ageing relies on the assumption that it is never too late to promote health, some health promotion activities only show benefits in a long-term perspective; thus, if applied to older people, they yield limited payback. This view is also shared in some EU documents where the lifespan approach to health promotion is indicated as being more effective. Furthermore, the neglect of health promotion might also result from the scarcity of scientific evidence of the effectiveness and cost-effectiveness of health promotion for older people [37-38]. To address this limitation, the EU facilitates the exchange of good practices (i.e. activities that, although not indicated in scrupulous scientific research, have been proven to work in given circumstances), through the European Innovation Partnership on Active and Healthy Ageing under the European growth strategy, Europe 2020. Although the partnership brought together various public and private actors and it has been a useful platform for sharing good practices and developing strategies for their further implementation, it has been criticized for its strong emphasis on innovation, which encourages the development of new technologies but does not always promote the most efficient measures to increase the number of Healthy Life Years. It has been noted that health promotion and disease prevention have not been properly addressed by the Partnership [39].

The results of our review show that, to influence country healthy ageing policy, the EU uses soft methods (providing guidelines and sharing good practices) with the aim of increasing awareness and encouraging member states and other relevant stakeholders to undertake actions. This approach results from the limited EU ability to shape countries' policies for disease prevention and health promotion [40]. Moreover, the diversity of needs of older people across countries, and within the population of the elderly, on the one hand, and the differences in the countries' capacity to address these needs (e.g. organization, funding and financing of health promotion) [41], on the other, might not accommodate a one size fits all approach. Nevertheless, the effectiveness of the nonbinding norms, which have been broadly formulated, is limited, and thus, countries' efforts to improve the health and wellbeing of older people might be insufficient.

In order to support member states and monitor their performance within population ageing polices, the EU has proposed two relevant tools: the Active Ageing Index and the Healthy Life Years (HLY) indicator. The Active Ageing Index is composed of various indicators, many of them, however, related to the active ageing concept (e.g. participation in the labour market and engaging in other unpaid activities). Thus, it measures the contributions of older people to society rather than wellbeing of older people, helping countries to identify the areas where the potential of older people is not being realized well. Health and quality of life, which are seen here as the capacity for active ageing, are reflected by the HLY indicator. Nevertheless, this indicator is not without limitations, and it is used for cross-country comparison with some caution [42].

Finally, the concept of healthy ageing may be seen as self-contradictory in its own meaning because old age is often associated with being unhealthy. Such perception is derived from an idea equalizing the process of ageing with disease [43-44]. A gradual amassing of physical and functional losses leads to many pathologies. Thus, the health of elderly people is statistically worse than in younger cohorts in an unavoidable way. However, 'the ageing process' - in WHO terminology - is seen as 'normal ageing', being unaffected by disease (in contrast to the pathological 'process of ageing'). In this sense, the expression "healthy ageing" is logically coherent [45]. When it is used in policy documents, its pervasive function might be an added value.

\section{Conclusions}

The EU has acknowledged that health is both a value in itself and that it can contribute to economic growth. Thus, it requires actions across different sectors as well as across the lifespan, including old age. The attention which the EU gives to the health and wellbeing of older people is an important step toward a better countrylevel healthy ageing policy. This might increase policy makers' awareness of the need to prepare age-specific health promotion and disease prevention strategies. The EU supports research and innovation though financial programmes which are targeted at the most common health problems of older people (e.g. falls). It also develops tools for monitoring progress, helping countries to 
identify the gaps in their policies. Furthermore, the EU facilitates the exchange of good practices and enables countries to learn from each other.

The achievements of EU policy on healthy ageing might, however, be overshadowed by the conceptual shortcoming and weaknesses of the policy measures used. This results from excluding the issue of healthy ageing, together with other social issues, from hard law regulations. Soft law methods, like the Open Method of Coordination, may be insufficient to motivate governments to act. Additionally, the distinction between healthy and active ageing remains blurred. This might incline country policy makers to focus on active ageing from the economic perspective, overlooking health promotion and disease prevention.

\section{References}

1. Eurostat, 2017, http://ec.europa.eu/eurostat/statistics-explained/index.php/Population_structure_and_ageing (accessed: 10.12.2016).

2. The Swedish National Institute of Public Health, Healthy Ageing-A Challenge for Europe, 2006, http://www.healthyageing. eu/sites/www.healthyageing.eu/files/resources/Healthy\%20 Ageing\%20-\%20A\%20Challenge\%20for\%20Europe.pdf (accessed: 10.12.2016).

3. WHO, World Report on Ageing and Health, Geneva 2015, http://apps.who.int/iris/bitstream/10665/186463/ 1/9789240694811_eng.pdf?ua=1 (accessed: 10.12.2016).

4. WHO, Health for all Targets. The Health Policy for Europe, Updated edition 1991, European HFA Series, No.4, Copenhagen 1993.

5. WHO, The World Health Report: 1998. Life in the $21^{\text {st }}$ century: A Vision for All, Geneva 1998.

6. Oxley H., Policies for Healthy Ageing: An Overview, OECD Health Working Papers, No. 42, OECD Publishing 2009.

7. Kaba-Schönstein L., Gesundheitsförderung IV: Die Europäische Gemeinschaft und Union als Akteur in der Gesundheitsförderung. Bundeszentrale für gesundheitliche Aufklärung (BZgA)(Hrsg.), Leitbegriffe der Gesundheitsförderung. Glossar zu Konzepten, "Strategien und Methoden der Gesundheitsförderung” 2003; 4: 88-95.

8. European Commission, Reflection Paper on the Social Dimension of Europe, 2017, https://ec.europa.eu/commission/ sites/beta-political/files/reflection-paper-social-dimensioneurope_en.pdf (accessed: 13.08.2017).

9. Byrne D., Enabling Good Health for All. A Reflection Process for a New EU Health Strategy, European Commission, 2004, http://eski.hu/new3/konyvtar/bookshop/Enabling\%20 good\%20health\%20for\%20all.pdf (accessed: 13.08.2017).

10. Walker A., Maltby T., Active Ageing: A Strategic Policy Solution to Demographic ageing in the European Union, "International Journal of Social Welfare" 2012; 21(s1): S117-S130.

11. Chłoń-Domińczak A., Kotowska I.E., Kurkiewicz J., Abramowska-Kmon A., Stonawski M., Population Ageing in Europe: Facts, Implications and Policies, European Commission, Brussels 2014.
12. Stegeman I., Otte-Trojel T., Costongs C., Considine J., Healthy and Active Ageing, EuroHealthNet and Bundeszentrale für gesundheitliche Aufklaerung (BZgA), Brussels 2012.

13. European Commission, Europe 2020. A European Strategy for Smart, Sustainable and Inclusive Growth, Communication from the Commission. $\operatorname{COM}(2010) 2020,2010$, http:// ec.europa.eu/eu2020/pdf/COMPLET\%20EN\%20BARROSO $\% 20 \% 20 \% 20007 \% 20-\% 20$ Europe $\% 202020 \% 20-\% 20$ EN\%20version.pdf (accessed: 15.06.2017).

14. Siddall C., Kjaeserud G., Healthy Ageing: Keystone for a Sustainable Europe - EU Health Policy in the Context of Demographic Change, Services of DG SANCO, DG ECFIN \& DG EMPL-European Commission, Brussels 2007.

15. Greer S.L., Fahy N., Elliott H.A., Wismar M., Jarman H., Palm W., Everything You Always Wanted to Know about European Union Health Policies but were Afraid to Ask, European Observatory on Health Systems and Policies, 2014.

16. Wohlin C., Guidelines for snowballing in systematic literature studies and a replication in software engineering. Proceedings of the 18th international conference on evaluation and assessment in software engineering, "ACM" 2014: 38.

17. Marzullo R., EU Policies on Healthy and Active Ageing. A Systematic Literature Review. Master's Thesis. Faculty of Health, Medicine and Life Sciences - Maastricht University, Maastricht 2016.

18. Council of the European Communities, Council Decision of 26 November 1990 on Community Actions for the Elderly, 1990, http://eur-lex.europa.eu/legal-content/EN/ TXT/HTML/?uri=CELEX:31991D0049\&rid=1 (accessed: 15.06.2017).

19. Council of the European Communities, Council Decision of 24 June 1992 on the Organization of the European Year of the Elderly and of Solidarity between Generations (1993), 1992, http://eur-lex.europa.eu/legal-content/EN/ TXT/HTML/?uri=CELEX:31992D0440\&rid=1 (accessed: 15.06.2017).

20. Kok W., Facing the Challenge: The Lisbon Strategy for Growth and Employment. Report from the High Level Group Chaired by Wim Kok, Office for Official Publications of the European Communities, Luxembourg 2004.

21. European Parliament, European Parliament Resolution on the Commission Communication 'Towards a Europe for all Ages - Promoting Prosperity and Intergenerational Solidarity', 2000, http://eur-lex.europa.eu/legal-content/EN/ TXT/PDF/?uri=CELEX:52000IP0319\&rid=1 (accessed: 7.08.2017).

22. Commission of the European Communities, Towards a Europe for All Ages - Promoting Prosperity and Intergenerational Solidarity, Communication from the Commission, 1999, http://ec.europa.eu/employment_social/social_situation/docs/com221_en.pdf (accessed: 7.08.2017).

23. Commission of the European Communities, Europe's Response to World Ageing. Promoting Economic and Social Progress in an Ageing World. A contribution of the European Commission to the 2nd World Assembly on Ageing, Communication from the Commission to the Council and the European Parliament, 2002, http://ec.europa.eu/employment_social/social_situation/docs/com2002_0143_en.pdf (accessed: 7.08.2017). 
24. Commission of the European Communities, Dealing with the Impact of an Ageing Population in the EU (2009 Ageing Report), Communication from the Commission to the European Parliament, the Council, the European Economic and Social Committee and the Committee of the Regions, 2009, http:// www.igfse.pt/upload/docs/gabdoc/2009/Novidades/05-Mai/ Communication_Dealing_with_the_impact_of_an_ageing population_en.pdf (accessed: 7.08.2017).

25. Council of the European Union, Council Conclusions on Healthy and Dignified Ageing. 2980th Employment, Social Policy, Health and Consumer Affairs Council Meeting, Brussels, 30 November 2009, http://www.salute.gov.it/ imgs/C_17_pagineAree_2406_listaFile_itemName_2_file. pdf (accessed: 7.08.2017).

26. Council of the European Union, Council Conclusions on Active Ageing. 3019th Employment, Social Policy Health and Consumer Affairs Council Meeting, Luxembourg, 7 June 2010, http://www.consilium.europa.eu/uedocs/ cms_data/docs/pressdata/en/1sa/114968.pdf (accessed: 7.08.2017).

27. Council of the European Union, Council Conclusions Healthy Ageing across the Lifecycle, 2012, http://eur-lex. europa.eu/legal-content/EN/ALL/?uri=CELEX\%3A52012 XG1221(01) (accessed: 7.08.2017).

28. European Parliament and Council of the European Union, Decision No 940/2011/EU of the European Parliament and Council of the European Union of 14 September 2011 on the European Year for Active Ageing and Solidarity between Generations (2012), 2011, http://eur-lex.europa.eu/ legal-content/EN/TXT/PDF/?uri=CELEX:32011D0940\&f rom=EN (accessed: 7.08.2017).

29. Tymowski J., European Year for Active Ageing and Solidarity between Generations, European Implementation Assessment. European Parliamentary Research Service, 2012, http://www.europarl.europa.eu/RegData/etudes/ IDAN/2015/536344/EPRS_IDA(2015)536344_EN.pdf (accessed: 7.08.2017).

30. UNECE, United Nations Economic Commission for Europe: Active Ageing Index, 2015, http://www1.unece.org/ stat/platform/display/AAI/I.+AAI+in+brief (accessed: 15.12.2016).

31. European Commission, Europe 2020 Flagship Initiative Innovation Union, Communication from the Commission to the European Parliament, the Council, the European Economic and Social Committee and the Committee of the Regions, 2010, http://eur-lex.europa.eu/legal-content/EN/ TXT/?qid=1502105593467\&uri=CELEX:52010DC0546 (accessed: 7.08.2017).

32. European Commission, Communication from the Commission to the European Parliament and the Council. Taking forward the Strategic Implementation Plan of the European Innovation Partnership on Active and Healthy Ageing, 2012, http://ec.europa.eu/health/ageing/docs/ com_2012_83_en.pdf (accessed: 7.08.2017).

33. European Parliament and Council of the European Union, Decision No 1786/2002/EC of the European Parliament and of the Council of 23 September 2002 Adopting a Programme of Community Action in the Field of Public Health (2003-2008) - Commission State- ments, 2002, http://eur-lex.europa.eu/legal-content/EN/ TXT/?uri=CELEX:32002D1786 (accessed: 7.08.2017).

34. European Parliament and Council of the European Union, Decision No 1350/2007/EC of the European Parliament and of the Council of 23 October 2007 Establishing a Second Programme of Community Action in the Field of Health (2008-2013), 2007, http://eur-lex.europa.eu/legal-content/ EN/TXT/?uri=celex:32007D1350 (accessed: 7.08.2017).

35. European Parliament and of the Council, Regulation (EU) No 282/2014 of the European Parliament and of the Council of 11 March 2014 on the Establishment of a Third Programme for the Union's Action in the Field of Health (2014-2020) and repealing Decision No 1350/2007/ EC, 2014, http://eur-lex.europa.eu/legal-content/en/ TXT/?uri=CELEX\%3A32014R0282 (accessed: 7.08.2017).

36. European Parliament and of Council of the European Union, Decision No 554/2014/EU of the European Parliament and of the Council of 15 May 2014 on the Participation of the Union in the Active and Assisted Living Research and Development Programme Jointly Undertaken by Several Member States, 2014, http://eur-lex.europa.eu/legalcontent/EN/TXT/?qid=1501523867409\&uri=CELEX:320 14D0554 (accessed: 7.08.2017).

37. Duplaga M., Grysztar M., Rodzinka M., Kopec A., Scoping review of health promotion and disease prevention interventions addressed to elderly people, "BMC Health Services Research" 2016; 16 (5): 278.

38. Dubas-Jakóbczyk K., Kocot E., Kissimova-Skarbek K., Huter K., Rothgang H., Economic evaluation of health promotion and primary prevention actions for older people - a systematic review, "The European Journal of Public Health" 2017; ckx030.

39. Ahtonen A., Healthy and Active Ageing: Turning the 'Silver' Economy into Gold'. Policy Brief, European Policy Centre, 2012, http://www.epc.eu/documents/uploads/ pub_1426_healthy_and_active_ageing.pdf (accessed: 7.08.2017).

40. Gericke C.A., Busse R., Policies for disease prevention in Germany in the European context: A comparative analysis, "Journal of Public Health" 2004; 26 (3): 230-238.

41. Arsenijevic J., Groot W., Tambor M., Golinowska S., Sowada C., Pavlova M., A review of health promotion funding for older adults in Europe: a cross-country comparison, "BMC Health Services Research" 2016; 16 (5): 288.

42. Jagger C., Gillies C., Moscone F., Cambois E., Van Oyen H., Nusselder W., Robine J.M., Inequalities in healthy life years in the 25 countries of the European Union in 2005: A cross-national meta-regression analysis, "The Lancet" 2008; 372(9656): 2124-2131.

43. Bulterijs S., Hull R.S., Björk V.C., Roy A.G., It is time to classify biological aging as a disease, "Frontiers in Genetics 2015; 6 .

44. Austad S.N., Making sense of biological theories of aging, in: M. Silverstein, V.L. Bengtson, M. Putnam, N.M. Putney, D. Gans (eds.), Handbook of theories of aging, Springer Publishing Company, New York 2008: 147-161.

45. WHO, Men, Ageing and Health: Achieving Health across the Life Span, Geneva 2001, http://apps.who.int/iris/bitstream/10665/66941/1/WHO_NMH_NPH_01.2.pdf (accessed: 13.08 .2017$)$. 